\section{IPCC: social scientists are ready}

Social scientists are ready to work as full partners with physicists and ecologists on climate-change assessments by the Intergovernmental Panel on Climate Change (IPCC), government agencies and other organizations (D. Victor Nature 520, 27-29; 2015).

Social scientists are already involved in climate discussions to some extent through societies of various disciplines (see, for example, go.nature.com/cixl9y). For more than 20 years, the US Board on Environmental Change and Society and the former International Human Dimensions Programme on Global Environmental Change have been examining the implications of socialscience research for global environmental change - and vice versa (see, for example, go.nature.com $/ 24 \mathrm{t} 7 \mathrm{mf}$ ).

However, social scientists can do more to engage with climate change by applying their disciplines and investigating human-environmental interactions that have their own dynamics. Further investment will help to develop integrated social and environmental data sets to support these analyses. These efforts will allow social scientists to test and expand the scope of their concepts and methods to contribute important insight into such relatively new issues.

Paul C. Stern National Research Council, Washington DC, USA. Thomas Dietz Michigan State University, East Lansing, Michigan, USA. pstern@nas.edu

\section{IPCC: calling social scientists of all kinds}

The invitation to contribute more to the Intergovernmental Panel on Climate Change (IPCC) should not be limited to social-science fields that are immediately relevant to decision-making processes, as David Victor seems to imply (see Nature 520, 27-29; 2015).

A wider mix of social scientists can more effectively contribute valuable knowledge to the often-contentious societal and policy issues around climate change. They will help to retain and strengthen the role of the IPCC in international policy-making and public discourse by using qualitative and quantitative, theoretical and empirical, basic and applied approaches.

This should not be difficult: most international socialscience associations have working groups on climate and environmental change, and integrated science platforms such as Future Earth involve hundreds of social scientists worldwide (www.futureearth. org). These social scientists should be equal partners in the IPCC's framing and scoping processes, along with their natural-scientist colleagues and policy-makers.

Mathieu Denis International Social Science Council, Paris, France.

Susanne C. Moser Future Earth, Santa Cruz, California, USA. mathieu@worldsocialscience.org

\section{Plant identification is key to conservation}

Isabel Marques' call to update traditional botany teaching beyond plant morphology seems to devalue the importance of taxonomy and systematics (Nature 520, 295; 2015). The identification of new plant species is still as relevant today as the discovery of new genes and gene functions and is crucial for conservation efforts in developing countries.

Enormous numbers of plant species in Brazil and Madagascar, for example, still await formal description. The skills needed to meet this challenge and their ability to attract funding should not

be dismissed. The Brazilian government is already providing funding, although it will be a long time before the Malagasy government can do so.

The botanical community is fast filling the gap between herbarium work and metagenomics, despite dwindling funding (see also M. Kemler Nature 521, 32; 2015).

A good place to start reviving interest in a botanical education, and hence strengthen this community, would be to include striking plant species such as Rafflesia and Sarracenia in televised nature programmes, rather than focusing on charismatic megafauna. Anna Trias-Blasi, Maria Vorontsova Royal Botanic Gardens, Kew, UK. a.triasblasi@kew.org

\section{Citizen science is not enough on its own}

Citizen scientists' important contributions to biodiversity conservation are constrained by their focus on data collection and public outreach in wealthy, accessible places. Sustainable conservation actions require initiatives such as those supported by the Participatory Monitoring and Management Partnership (www.pmmpartnership.com), in which data collected by land owners and resource users help to guide local decision-makers on conservation management.

Citizen scientists do not formulate research questions, analyse data or implement management solutions on the basis of research findings. By contrast, participatory monitoring by local and indigenous communities in tropical, Arctic and developing regions enables them to propose solutions for environmental problems, advance sustainable economic opportunities, exert management rights and contribute to global environmental data sets.

Such monitoring could benefit from the large-scale databases and knowledge integration pioneered by citizen science. Conversely, citizen science could benefit from the community-based monitoring practices used to build datacollection methods, analytical tools, communication networks and skilled workforces in culturally appropriate, placebased governance structures. Rod Kennett Australian Institute for Aboriginal and Torres Strait Islander Studies, Canberra, Australia.

Finn Danielsen NORDECO, Copenhagen, Denmark.

Kirsten M. Silvius Virginia Tech University, Blacksburg, Virginia, USA.

rod.kennett@aiatsis.gov.au

\section{Check the rejects for fame bias too}

Omid Mahian and colleagues suggest that scientific celebrity does not seem to influence the editors' choice of Correspondence items for publication (Nature 519, 414 ; 2015), but their informal analysis has caveats beyond those they mention.

Famous authors may be more disposed to write letters to the editor than is the rest of Nature's readership, for example. Any analysis for editorial bias should include data from rejected contributions as well (which were obviously unavailable to the authors). Then, applying a logistic regression or calculating an index of niche breadth, such as the proportional similarity index (P. Feinsinger et al. Ecology 62, 27-32; 1981), would clinch the matter.

Perhaps a simpler demonstration of a lack of editorial bias might be the publication of this note, signed by a student who has no publishing record at all. Davide Nespoli University of Milan, Italy. davide.nespoli@unimi.it 